\title{
Integrated Marketing Communications Sharia Banking Economy
}

\author{
Sa'diyah El Adawiyah ${ }^{1, *}$, Tria Patrianti ${ }^{2}$, Meilani Dhamayanti ${ }^{3}$, Nurul Intan Pratiwi ${ }^{4}$, \\ Siti Seituni ${ }^{5}$, Rahmanita Ginting ${ }^{6}$ \\ ${ }^{I}$ Department of Communication Science, Universitas Muhammadiyah Jakarta, Indonesia \\ ${ }^{2}$ Department. of Communication Science, Universitas Muhammadiyah Jakarta, Indonesia \\ ${ }^{3}$ Department of Communication Science, Bina Nusantara University, Jakarta, Indonesia \\ ${ }^{4}$ Department of Publishing Politeknik Negeri Jakarta, Depok, West Java, Indonesia, \\ ${ }^{5}$ Department of Publishing, STKIP PGRI Situbondo, Indonesia \\ ${ }^{6}$ Master of Communication Postgraduate Program Universitas Muhammadiyah Sumatera Utara, Medan, Indonesia \\ ${ }^{*}$ Corresponding author.Email: sadiyah.eladawiyah@umj.ac.id
}

\begin{abstract}
Integrated marketing communication is a communication process used by Islamic Banking in Indonesia to market their financial solutions to various people. In building the Islamic banking economy, IMC combines advertising, personal selling, sales promotion, public relations and publicity, and direct marketing into a unified unit. This study is a literature study of various Islamic banking finance companies that have used IMC to improve their offerings. These findings indicate that Islamic Banking has utilized Integrated Marketing Communications in various methods to educate, promote, strengthen and introduce Islamic financial banking, depending on their specific needs
\end{abstract}

\section{Keywords: Integrated Marketing Mix Communications, Sharia Banking}

\section{INTRODUCTION}

Indonesia has two banking operational systems, namely conventional banks and Islamic banks. Islamic banking is a banking based on Islamic law (sharia) according to the Qur'an (Qs. An-nisaa: 160 - 161) and the Law. No. 21 of 2008 concerning Islamic banking. In accordance with the fatwa of the Indonesian Ulema Council, Islamic banking is a bank that carries out business activities based on sharia principles or Islamic legal principles with the principles of justice and balance ('adl wa tawazun), benefit (maslahah), universalism, does not contain usury, gharar, maysir. , unjust or unlawful by carrying out social functions that receive funds from zakat, infaq, alms, grants and distribute them to waqf managers (nazhir), according to the will of the waqf giver (wakif).

The majority of Muslims in Indonesia use Islamic economic services through Islamic banking and it is possible that other countries such as China, Britain, France are interested in using Islamic or Islamic economic services and even develop these service products. The awareness of producers that Muslim consumers are easy targets for marketing their products through the Islamic Branding label [1] is using Islamic identity (with the words Islam, Sharia, Islamic names, halal labels) in marketing their products.

Erol, Kaynak and El-Bdour in their research [2], [3] concludes that religious factors do not influence customers to use Islamic banks, fast and efficient services, costs and benefits, bank reputation and image and confidentiality are important factors for customers to choose Islamic banks.

Based on the observations of Omer (1992), Metwally (1996) and H.S. Okumus (2005) in his research concludes that religious factors and usury-free banking products have a significant influence on customer attitudes in choosing Islamic banks [4]. Facts on the ground, consumers as users of Islamic economic service products through Islamic banking do not yet understand the material differences between Islamic banking economic products and conventional banking other than image [1], that Islamic banking economic services are free from usury while conventional banking contains elements of usury which is prohibited by religion. 
Duncan divided 5 (five) Integrated Marketing Communications activities, namely advertising, personal selling, sales promotion, public relations, and direct marketing. The application of IMC according to Kotler goes through the following steps: identifying the target audience, determining communication objectives, designing messages, selecting communication channels, determining the amount of marketing communications budget, and making decisions on the marketing communication mix.

\subsection{Islamic Bank}

Based on Law No. 21 of 2008 [1] is a financial institution that uses sharia principles in accordance with the Quran and Hadith which aims to: 1) direct the economic activities of the people to muamalah in Islam, especially muamalah related to banking in order to avoid the practice of usury ,2) improving the quality of life of the people by opening up business opportunities, and 3) maintaining the government's economic or monetary stability through sharia banking activities.

\section{METHOD}

Ther research method uses qualitative methods through literature studies from various existing research studies related to Islamic finance integrated marketing communications

\section{RESULT AND DISCUSSION}

The need to introduce Islamic economics and Islamic banking needs to be done in various ways. Based on the results of research the low level of public literacy and financial inclusion in the Islamic finance industry in Indonesia makes the number of users of Islamic financial services in Indonesia still minimal. So that Islamic finance in this case Islamic banking needs to promote by using marketing tools to increase and increase the number of customers and the image of Islamic banking itself. Integrating marketing communications according to Duncan is an integrated marketing communication mix which includes five (Integrated Marketing Communication activities, namely advertising, personal selling, sales promotion, public relations, and direct marketing.

\subsection{Advertising}

Marketing through advertising is done both using conventional media such as television, radio, print and electronic media as well as adding new media, namely social media using internet networks. Compared to conventional media, new media, namely social media has a fairly rapid development, especially in Indonesia with an increasing number of active users. The social media in question, namely twitter, instagram, facebook and tiktok, 
youtube, and websites have their respective advantages and disadvantages. However, of all existing social media, Instagram is very effective in marketing Islamic financial products. The presence of business Instagram has more diverse features and can be adjusted according to the wishes of the recipient of the ad that can be adjusted according to location, age, interest in the product. Messages can be adjusted through education and persuasion to invest and invite prospective customers to move from conventional finance to Islamic finance [6]. For example this is also done by BRI Syariah using advertising through below the line and above the line in promoting Faedah savings [7]. Above the line, BRI Syariah conducted advertisements in other mass media such as print media through newspapers, brochures, radio, TV. Meanwhile, below the line through BRI Syariah staff.

\subsection{Personal selling}

The marketing communication strategy through direct selling or personal selling is the most personal promotional strategy compared to other promotion mixes, because it allows two-way communication, either face to face or by telephone, video or web conference [5].The form of personal selling activities in the form of executive selling places the company leadership as a sales person PT Alami Shariah uses personal selling by involving several influential influencers, opinion leaders, or scholars [5] with the aim of building awareness, driving consumer interest, attracting new consumers, as well as conducting market analysis [7].

\subsection{Sales Promotion}

Conducted to attract consumer interest in Islamic financial products. In contrast to conventional financial products that can provide promos to attract new potential customers. One of the Islamic finance, namely BNI Syariah, promotes its products through an open table event on a predetermined day [7]. Islamic fintech uses extra ujroh services which are profit sharing services using the Alami application [6] with the aim of increasing repeat purchases according to Cummis and Mullin.

\subsection{Public Relations \& Publicity}

Build and form a positive image of the public both internally and externally, especially customers [7]. The purpose of public relations is to improve the relationship between products and consumers and society in general [7] other objectives are to increase awareness, inform and educate, gain understanding, build trust, give consumers reasons to buy products, and motivate consumer acceptance, Belch and Belch in.

\subsection{Direct Marketing}

Direct marketing activities so that there is interaction between consumers or customers with personal media such as cellphones, emails, telephones and others [8]. Direct marketing at Fintek Shariah uses two channels, namely Customer relations management and group communication using social media such as WhatsApp and Telegram [9].

Alami's integrated marketing communication products found that digital advertising, digital personal selling, digital sales promotion, digital public relations, digital direct marketing activities have been carried out and have had a positive influence or encourage purchases.

\section{CONCLUSION}

Integrated marketing communications sharia banking economying finance has carried out various ways through integrated marketing communications to educate, remind consumers, and also the general public through advertising, promotion, public relations \& publicity, direct marketing.

\section{AUTHORS' CONTRIBUTIONS}

All the authors in this article have contributed equally in building research logic, language improvements and template customization.

\section{ACKNOWLEDGMENTS}

The author would like to thank various parties, both friends and colleagues who supported so that this paper can be completed.

\section{REFERENCES}

[1] Santoso, I., \& Adawiyah, S. El. (2019). Branding Islam dan Religiusitas Individu pada Keputusan Nasabah dalam Menggunakan Produk Bank Syariah. Journal of Business \& Entepreneurship, 2(1), 1-12. https://doi.org/10.24853/baskara.2.1.1$\underline{12}$

[2] Iskamto, D., \& Yulihardi. (2017). Analisis Peranan Religiusitas Terhadap Kepercayaan Kepada Perbankan Syariah. Magdis, Jurnal Kajian Ekonomi Islam -, 02 (Juli-Desember 2017), 206-214. http://journal.febi.uinib.ac.id/index.php/maqdis/arti cle/view/129

[3] Hisanuddin, L. I. (2015). Pengaruh Citra Merek Islam Terhadap Loyalitas Nasabah Bank Syariah. Scientica, II(2), 87-100.

[4] Annabi, C. A., Husein, U. M., Hassan, F., \& Nasir, N. (2017). Sharia Compliance In The Construction 
Industry: Is This Something To Build Upon? Journal of Emerging Economies and Islamic Research, 5(1), 9.

https://doi.org/10.24191/jeeir.v5i1.8793

[5] Hisanuddin, L. I. (2015). Pengaruh Citra Merek Islam Terhadap Loyalitas Nasabah Bank Syariah. Scientica, II(2), 87-100.

[6] Bisnis, J. L., Pramudita, A. S., Studi, P., Bisnis, L., \& Indonesia, P. P. (2017). Model Saluran Integrated Marketing Communication Bri. 7(1), 12-23.

[7] Entaresmen, R. A. (n.d.). Hasanah Di Pt . Bank Negara Indonesia Syariah Kantor Cabang X. 53-74.

[8] Noveriyanto, B., Adawiyah, E., Magister, P., Komunikasi, I., \& Jakarta, U. M. (2021). ( DIMC ) Activities Of Digital Products Financial Technology ( Fintech ) “Alami . 14 (1), 60-73.

[9] Saudiah, R., Putri, D., Julianto, D. E., \& Handini, Y. D. (2013). Komunikasi Pemasaran pada PT . Bank Syariah Mandiri Kantor Cabang Pembantu Surabaya-Barata Dalam Menarik Minat Nasabah ( Marketing Communication at PT . Bank Syariah Mandiri Surabaya-Barata Assistance Branch Office in Interest To Customer ). 72 